\title{
PENGARUH KOMITMEN PROFESI, SIKAP KERJA DAN STRES KERJA TERHADAP KINERJA PEGAWAI BIDANG KEDOKTERAN DAN KESEHATAN KEPOLISIAN DAERAH SUMATERA UTARA
}

\author{
${ }^{1}$ Lailatusy Syfa S., ${ }^{2}$ Muhammad Caesar Akbar, ${ }^{3}$ Irfan Nurddi Syah, ${ }^{4}$ Betia Warassari, ${ }^{5}$ Aivan Saleh \\ Alfaouzan Siregar \\ 1,2,3,4,5 Universitas Islam Sumatera Utara \\ ${ }^{1}$ lailatusy.syifa@gmail.com, ${ }^{2}$ mhdcaesar.akbar@gmail.com, ${ }_{5}^{3}$ irfan.nurddisyah@gmail.com, ${ }_{5}^{4}$ betia.warassari@gmail.com, \\ 5 aivansaleh.alfaozan@gmail.com
}

\begin{abstract}
The Formulation of this research is how the professional commitment, work attitude, and occupational stress to the performance of Medical And Health Officers Of The North Sumatera Region Police, and the purpose of this research is to know and analyze the influence of professional commitment, work attitude, and occupational stress to the performance of Medical And Health Officers Of The North Sumatera Region Police. This research is a quantitative descriptive study. Data collection techniques are conducted through interviews, inquiry lists and documentation studies. The samples in this study were as many as 95 employees. Variables are measured at Likert scale. Hypothesis testing using multiple linear regression analyses through $F$ test and T-Test. The Results of the test in Unison showed that professional commitment, work attitude, and occupational stress demonstrated a very noticeable influence to the performance of Medical And Health Officers Of The North Sumatera Region Police, with the value $F_{\text {count }}$ 50,032 > $F_{\text {table }} 2.70$ and significance value of $0.000^{b}$. Adjusted number of $R$ Square by 0.610 or (61\%) indicates that the percentage of contribution of independent variable influence (profession commitment, work attitude, and occupational stress) to the dependent variable (employee performance) was $61 \%$. Partially, the commitment of the profession positively influence to the performance of Medical And Health Officers Of The North Sumatera Region Police with a value of $t_{\text {count }}>t_{\text {table }}(7,876>1,985)$ and a significance value of 0.000. Working attitude is positive and significant to the performance of Medical And Health Officers Of The North Sumatera Region Police, with the value $t_{\text {count }}>t_{\text {table }}(7,006>1,985)$ and significance value of 0.00 . Work stress is negatively and significantly affected by the performance of Medical And Health Officers Of The North Sumatera Region Police with a value of $t_{\text {count }}<t_{\text {table }}(-3,352<1,985)$ and the significance value of 0. 001. The highest value of a regression coefficient is a professional commitment $\left(X_{1}\right)$ of 0.529 or $52.9 \%$ and is the most dominant variable affecting to the performance of Medical And Health Officers Of The North Sumatera Region Police.
\end{abstract}

Keywords: Professional Commitment, Work Attitude, Work stRess, Employee Performance.

ABSTRAK : Rumusan pada penelitian ini adalah bagaimana pengaruh komitmen profesi, sikap kerja, dan stres kerja terhadap kinerja pegawai Bidang Kedokteran dan Kesehatan Kepolisian Daerah Sumatera Utara, dan tujuan penelitian ini adalah untuk mengetahui dan menganalisis pengaruh komitmen profesi, sikap kerja, dan stres kerja terhadap kinerja pegawai Bidang Kedokteran dan Kesehatan Kepolisian Daerah Sumatera Utara.

Penelitian ini merupakan penelitian deskriptif kuantitatif. Teknik pengumpulan data dilakukan melalui wawancara, daftar pertanyaan dan studi dokumentasi. Sampel dalam penelitian ini sebanyak 95 orang pegawai. Variabel diukur dengan skala Likert. Pengujian hipotesis menggunakan analisis regresi linear berganda melalui uji $F$ dan uji $t$.

Hasil uji secara serempak menunjukkan bahwa komitmen profesi, sikap kerja, dan stres kerja menunjukkan pengaruh sangat nyata terhadap kinerja pegawai Bidang Kedokteran dan Kesehatan Kepolisian Daerah Sumatera Utara dengan nilai $F_{\text {hitung }} 50.032>F_{\text {tabel }} 2.70$ dan nilai signifikansi sebesar $0.000^{b}$. Angka Adjusted R Square sebesar 0.610 atau (61\%) menunjukkan bahwa persentase sumbangan pengaruh variabel independen (komitmen profesi, sikap kerja, dan stres 
kerja) terhadap variabel dependen (kinerja pegawai) sebesar 61\%. Secara parsial, komitmen profesi berpengaruh positif terhadap kinerja pegawai Bidang Kedokteran dan Kesehatan Kepolisian Daerah Sumatera Utara dengan nilai $t_{\text {hitung }}>t_{\text {tabel }}(7.876>1.985)$ dan nilai signifikansi sebesar 0.000. Sikap kerja berpengaruh positif dan signifikan terhadap kinerja pegawai Bidang Kedokteran dan Kesehatan Kepolisian Daerah Sumatera Utara dengan nilai $t_{\text {hitung }}>t_{\text {tabel }}(7.006>$ 1.985) dan nilai signifikansi sebesar 0.00. Stres kerja berpengaruh negatif dan signifikan terhadap kinerja pegawai Bidang Kedokteran dan Kesehatan Kepolisian Daerah Sumatera Utara dengan nilai $t_{\text {hitung }}<t_{\text {tabel }}(-3.352<1.985)$ dan nilai signifikansi sebesar 0.001. Nilai koefisien regresi yang paling tinggi adalah komitmen profesi $\left(X_{1}\right)$ sebesar 0.529 atau 52,9\% dan merupakan variabel yang paling dominan mempengaruhi kinerja pegawai Bidang Kedokteran dan Kesehatan Kepolisian Daerah Sumatera Utara.

Kata kunci: Komitmen profesi, Sikap kerja, Stres kerja, Kinerja Pegawai.

\section{Pendahuluan}

Kinerja pegawai merupakan hasil proses yang kompleks, baik berasal dari diri pribadi pegawai (internal factor) maupun upaya strategis dari organisasi. Menurut pendapat Colquitt at.al (2009:273), kinerja adalah nilai dari seperangkat perilaku pegawai yang berkontribusi secara positif dan negatif untuk mencapai tujuan organisasi. Kinerja memiliki 3 (tiga) dimensi yaitu perilaku tugas, perilaku moral dan perilaku menantang. Perilaku tugas adalah tingkah laku pegawai yang terlibat secara langsung dalam mentransformasikan sumber organisasi dalam kebajikan, pelayanan atau produksi organisasi. Perilaku tugas meliputi tugas rutin dan tugas dalam pembaharuan. Perilaku moral adalah aktivitas dalam bentuk kesukarelaan dari pegawai ada reward atau tidak ada reward akan tetapi tetap memberikan kontribusi pada organisasi guna memperbaiki kualitas secara keseluruhan di tempat kerja.

Berdasarkan survei awal yang peneliti lakukan di Bidang Kedokteran dan Kesehatan Kepolisian Daerah Sumatera Utara dapat penulis kemukakan variabel pertama yang mempengaruhi kinerja pegawai adalah komitmen profesi. Menurut pendapat Krietner (2011:135), mendefenisikan komitmen profesi sebagai sebuah konsep yang memiliki tiga dimensi yaitu affective, normative, dan continuance commitment. Affective commitment adalah tingkat seberapa jauh seorang pegawai secara emosional terikat, mengenal, dan terlibat dalam organisasi. Continuance commitment adalah suatu penilaian terhadap biaya yang terkait dengan meninggalkan organisasi. Normative commitment merujuk kepada tingkat seberapa jauh seseorang secara phsychological terikat untuk menjadi pegawai dari sebuah organisasi yang didasarkan kepada perasaan seperti kesetiaan, afeksi, kehangatan, kepemilikan, kebanggaan, kesenangan, kebahagian, dan lain-lain. Penelitian terdahulu yang terkait pada komitmen profesi, yaitu penelitian yang dilakukan oleh Yuwalliatin, S. (2006), dengan hasil penelitian bahwa komitmen profesi berpengaruh terhadap kinerja. Fenomena yang terjadi di Bidang Kedokteran dan Kesehatan Kepolisian Daerah Sumatera Utara diantaranya masih terdapat kesenjangan atas pemahaman berbagai peraturan yang berhubungan dengan penyelenggaraan administrasi kesehatan dan masih terdapat keterlambatan dalam proses pelayanan ke stakeholders terkait.

Variabel kedua teridentifikasi mempengaruhi kinerja pegawai Bidang Kedokteran dan Kesehatan Kepolisian Daerah Sumatera Utara adalah sikap kerja. Menurut Ivancevich (2007:88), sikap kerja merupakan keadaan mental yang dipelajari dan diorganisasikan melalui pengalaman, menghasilkan pengaruh spesifik pada respons seseorang terhadap orang lain, objek, dan situasi yang berhubungan. Teori Roe (1999:116), menyatakan bahwa orang mencari kesesuaian antara keyakinan dan perasaan mereka terhadap objek dan menyatakan bahwa modifikasi sikap dapat dilakukan dengan mengubah sisi perasaan atau keyakinan tersebut, teori tersebut berpendapat bahwa kognisi, afeksi dan perilaku menentukan sikap dan bahwa sikap pun pada akhirnya menentukan kognisis, afeksi dan perilaku.

Penelitian terdahulu yang menjelaskan bahwa sikap kerja berpengaruh atau tidak berpengaruh terhadap kinerja pegawai, pertama penelitian dari Noviansyah (2011) menguji tentang pengaruh sikap kerja terhadap kinerja, kepuasan kerja, dan komitmen organisasi pada 65 staf PT. Perkebunan Minanga Ogan 
Baturaja. Hasil penelitian menjelaskan bahwa bahwa sikap kerja memiliki pengaruh positif tetapi tidak signifikan terhadap kinerja. Kedua penelitian dari Liao (2012), menguji tentang work values, work attitudes and job performance of Green Energy Industry Employee in Taiwan pada 485 pegawai dan direktur dari 48 organisasi green energy, hasil penelitian menjelaskan bahwa sikap kerja tidak berpengaruh terhadap kinerja pegawai. Berdasarkan hasil penelitian dari Noviansyah (2011) dan Liao (2012), yang menguji pengaruh sikap kerja terhadap kinerja mempunyai hasil yang berbeda, oleh karena itu perlu kiranya dilakukan penelitian lagi untuk memperjelas hubungan kausal antara sikap kerja terhadap kinerja, terutama di Bidang Kedokteran dan Kesehatan Kepolisian Daerah Sumatera Utara.

Variabel ketiga yang teridentifikasi mempengaruhi kinerja pegawai Bidang Kedokteran dan Kesehatan Kepolisian Daerah Sumatera Utara adalah stres kerja. Robbins (2007:43) menjelaskan stres kerja adalah kondisi yang muncul dari interaksi antara pegawai dengan pekerjaan serta dikarakteristikkan oleh perubahan manusia yang memaksa mereka untuk menyimpang dari fungsi normal mereka. Gejala stres kerja ini dapat dilihat antara lain emosi tidak stabil, perasaan tidak tenang, suka menyendiri, sulit tidur, merokok yang berlebihan, tidak bisa rileks, cemas, tegang, gugup, tekanan darah meningkat, dan mengalami gangguan pencernaan. Stres kerja yang dialami oleh pegawai akan membawa dampak negatif terhadap motivasi kerja, artinya pegawai yang memiliki tingkat stres kerja tinggi cendrung memiliki kinerja yang rendah dan pada akhirnya berdampak penurunan kinerja pegawai tersebut. Untuk dapat mengungkap fenomena tentang stres kerja pegawai Bidang Kedokteran dan Kesehatan Kepolisian Daerah Sumatera Utara, dilakukan pengamatan dengan cara wawancara secara lisan terhadap 10 orang pegawai yang pernah tidak masuk kerja karena sakit. Dari hasil wawancara tersebut penulis menemukan kebanyakan dari mereka yang sakit disebabkan karena gangguan pencernaan, sulit tidur dan tekanan darah tinggi, dimana hal-hal tersebut merupakan gejala seseorang mengalami stres kerja.

\subsection{Batasan Masalah}

Berdasarkan pada uraian di atas, banyak faktor yang teridentifikasi terkait pada variabel penelitian. Oleh karena itu peneliti membatasi permasalahan dalam penelitian ini hanya pada masalah komitmen profesi, sikap kerja, stres kerja dan dan kinerja pegawai.

\subsection{Hioptesis}

Berdasarkan uraian teoretis, penelitian terdahulu dan kerangka konseptual yang telah dikemukakan di atas, maka dapat ditarik hipotesis penelitian ini sebagai berikut :

1) Komitmen profesi berpengaruh positif dan signifikan terhadap kinerja pegawai Bidang Kedokteran dan Kesehatan Kepolisian Daerah Sumatera Utara.

2) Sikap kerja berpengaruh positif dan signifikan terhadap kinerja pegawai Bidang Kedokteran dan Kesehatan Kepolisian Daerah Sumatera Utara.

3) Stres kerja berpengaruh positif dan signifikan terhadap kinerja pegawai Bidang Kedokteran dan Kesehatan Kepolisian Daerah Sumatera Utara.

4) Komitmen profesi, sikap kerja dan stres kerja berpengaruh positif dan signifikan terhadap kinerja pegawai Bidang Kedokteran dan Kesehatan Kepolisian Daerah Sumatera Utara.

\subsection{Tujuan Penelitian}

Tujuan dari penelitian ini adalah :

1) Untuk mengetahui dan menganalisis pengaruh komitmen profesi terhadap kinerja pegawai Bidang Kedokteran dan Kesehatan Kepolisian Daerah Sumatera Utara.

2) Untuk mengetahui dan menganalisis pengaruh sikap kerja terhadap kinerja pegawai Bidang Kedokteran dan Kesehatan Kepolisian Daerah Sumatera Utara.

3) Untuk mengetahui dan menganalisis pengaruh stres kerja terhadap kinerja pegawai Bidang Kedokteran dan Kesehatan Kepolisian Daerah Sumatera Utara.

4) Untuk mengetahui dan menganalisis pengaruh komitmen profesi, sikap kerja dan stres kerja terhadap kinerja pegawai Bidang Kedokteran dan Kesehatan Kepolisian Daerah Sumatera Utara.

\section{Metode Penelitian}

\subsection{Populasi}

Menurut Sugiyono (2009:90), populasi adalah wilayah generasi yang terdiri dari atas objek/subjek yang mempunyai kualitas 
karakteristik tertentu yang disajikan oleh peneliti untuk dipelajari dan kemudian ditarik kesimpulannya. Berdasarkan defenisi tersebut, maka populasi dalam penelitian ini adalah para pegawai Bidang Kedokteran dan Kesehatan Kepolisian Daerah Sumatera Utara yang berjumlah 95 orang, dimana Kepala Bidang dan peneliti tidak disertakan sebagai populasi, dengan rincian sebagai berikut :

Tabel 1. Kerangka Populasi Pegawai

\begin{tabular}{|c|l|c|}
\hline No & \multicolumn{1}{|c|}{ Keterangan } & Jumlah \\
\hline 1. & Kepala Sub Bagian & 1 \\
\hline 2. & Kepala Urusan (KAUR) & 9 \\
\hline 3. & Kepala Sub Bidang & 2 \\
\hline 4. & Penata Urusan (PAUR) & 6 \\
\hline 5. & Pelaksana & 77 \\
\hline \multicolumn{2}{|l|}{ Jumlah } & 95 \\
\hline
\end{tabular}

Sumber : Bidang Kedokteran dan Kesehatan Polda Sumut, 2020

\subsection{Sampel}

Menurut Sugiyono (2009:93), sampel adalah elemen-elemen populasi yang dipilih atas dasar kemampuan mewakilinya. Untuk menjadi pedoman jika subjeknya atau populasinya kurang dari 100, maka lebih baik diambil semua sebagai sampel, sehingga penelitiannya merupakan penelitian populasi. Selanjutnya jika jumlah subjeknya atau populasinya besar atau lebih dari 100, maka dapat diambil persentasenya. Dengan teknik penarikan sampel secara total sampling, maka sampel dalam penelitian ini seluruh populasi yaitu 95 orang pegawai Bidang Kedokteran dan Kesehatan Kepolisian Daerah Sumatera Utara.

\subsection{Uji Normalitas}

Uji normalitas bertujuan untuk menguji apakah dalam model regresi variabel pengganggu (residual) memiliki distribusi normal. Seperti diketahui bahwa uji " $t$ " dan uji F mengasumsikan bahwa nilai residual mengikuti distribusi normal.

Dalam penelitian ini pengujian normalitas dideteksi melalui analisa grafik P-P Plot.yang dihasilkan melalui SPSS. Adapun output grafik P-P Plot seperti terlihat pada gambar dibawah ini:

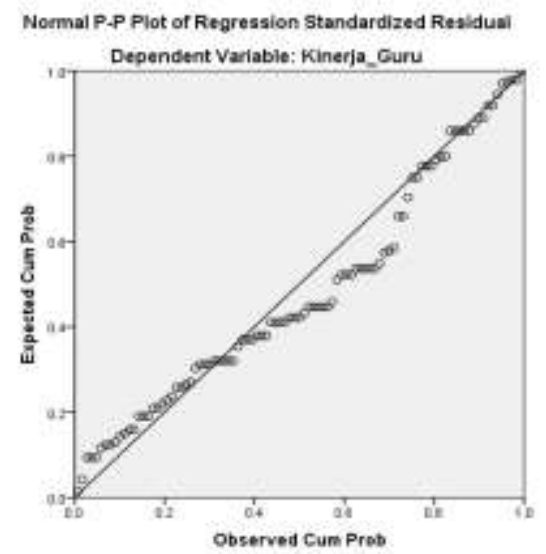

Gambar 1. Uji normalitas P-P Plot Test

Berdasarkan gambar 1, di atas, terlihat bahwa distribusi dari titik-titik data komitmen profesi, sikap kerja, stres kerja dan kinerja menyebar. Grafik P-P Plot diatas menunjukan bahwa sebaran data menyebar disekitar garis diagonal, sehingga asumsi normalitas dipenuhi. Maka model regresi layak dipakai untuk memprediksi kinerja berdasarkan variabel independennya.

Berdasarkan gambar 2 dibawah terlihat bahwa grafik histogram memberikan pola distribusi normal tidak berpola distribusi melenceng (swewness) ke kiri atau ke kanan, maka model regresi memenuhi asumsi normalitas.

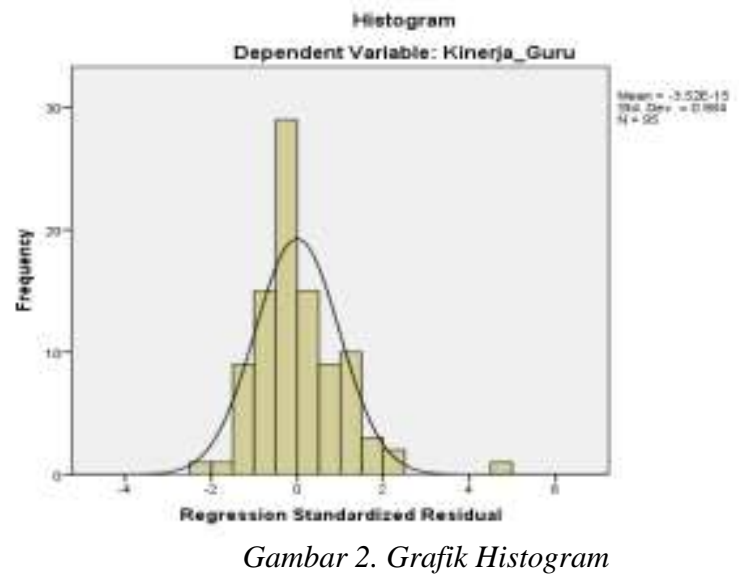

\subsection{Uji Multikolinearitas}

Metode untuk menguji ada tidaknya multikolinearitas dapat dilihat Tolerance Value dan Inflation Factor (VIF). Batas tolerance value adalah 0,10 atau nilai VIF adalah 10. Jika tolerance value $>0,10$ dan $\mathrm{VIF}<10$ maka tidak terjadi multikolinearitas dan sebaliknya jika tolerance value < 0,10 dan VIF $>10$ maka terjadi multikoleniaritas. Hasil pengolahan dapat dilihat pada tabel 5.14 berikut ini: 
Tabel 2. Uji Multikolinearitas Coefficients $^{\mathrm{a}}$

\begin{tabular}{|c|c|c|}
\hline \multirow[t]{2}{*}{ Model } & \multicolumn{2}{|c|}{$\begin{array}{c}\text { Collinearity } \\
\text { Statistics }\end{array}$} \\
\hline & Tolerance & VIF \\
\hline (Constant) & & \\
\hline Komitmen_Profes & .920 & 1.087 \\
\hline Sikap_Kerja & .939 & 1.065 \\
\hline Stres_Kerja & .978 & 1.023 \\
\hline
\end{tabular}

Sumber: Hasil Pengolahan SPSS Tahun 2020

Berdasarkan output tabel 2 diatas, hasil perhitungan nilai tolerance menunjukan tidak ada variabel independen yang memiliki nilai tolerance kurang dari 0,10 yang berarti tidak ada korelasi antara variabel independen yang nilainya lebih dari $95 \%$. Hasil perhitungan nilai variance inflaction factor (VIF) juga menunjukan hal yang sama, yaitu tidak ada satu variabel independen yang memiliki nilai VIF lebih dari 10. Jadi dapat disimpulkan bahwa tidak ada multikolinieritas antar variabel independen dalam model regresi.

\subsection{Uji Heteroskedastisitas}

Uji heteroskedastisitas dilakukan untuk mengetahui apakah dalam sebuah model regresi terjadi ketidaksamaan varians dari residual suatu pengamatan ke pengamatan lain. Jika varians dari residual dari suatu pengamatan ke pengamatan lain tetap disebut heteroskedastisitas.

Menganalisis data dalam pengujian asumsi klasik ini, peneliti menggunakan Program Statistical Product and Service Solution (SPSS) for Windows dapat dilihat pada gambar 3 berikut ini:

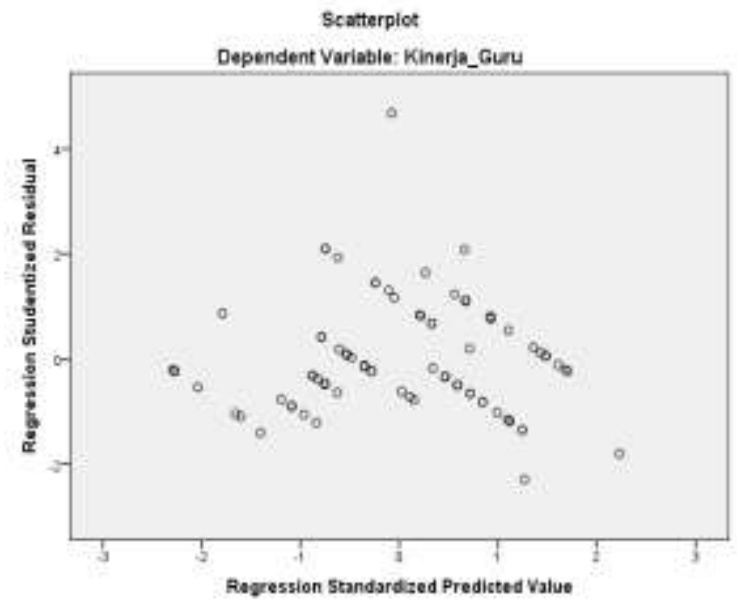

Gambar 3. Grafik scatterplot Uji Heteroskedastisitas
Dari gambar di atas menunjukkan bahwa diagram pencar tidak membentuk suatu pola atau acak, dengan demikian dapat dikatakan bahwa regresi tidak mengalami gangguan heteroskedastisitas pada model regresi sehingga model regresi layak dipakai untuk mengetahui kinerja pegawai (Y) berdasarkan variabel bebasnya.

\subsection{Uji Autokorelasi}

Uji autokorelasi digunakan untuk melihat hubungan antara variabel bebas memiliki hubungan sama kuat atau tidak, dimana untuk melihat hubungan atau tidak hubungan secara autokorelasi dapat dilihat dengan Uji DurbinWatson (DW test)

Uji Durbin-Watson hanya digunakan untuk autokorelasi tingkat satu (first order autocorrelation) dan mensyaratkan adanya intercept (kostanta) dalam model regresi dan tidak ada variabel lain diantara variabel independent.

Tabel 3. Uji Durbin-Watson (DW test) Model Summary ${ }^{\text {b }}$

\begin{tabular}{|l|r|r|r|r|}
\hline \multirow{2}{*}{ Model } & \multicolumn{3}{|c|}{ Change Statistics } & Durbin- \\
\cline { 2 - 4 } & $\mathrm{df1}$ & $\mathrm{df} 2$ & $\begin{array}{c}\text { Sig. F } \\
\text { Change }\end{array}$ & \\
\hline 1 & $3^{\mathrm{a}}$ & 91 & .000 & 1.898 \\
\hline
\end{tabular}

Sumber: Hasil Pengolahan SPSS Tahun 2020

Berdasarkan tabel 3 diatas diperoleh nilai Durbin-Watson sebesar 1.898. Nilai DurbinWatson menurut tabel dengan $\mathrm{n}=95$ responden dan $\mathrm{K}=3$ (dalam hal ini adalah jumlah variabel bebas) didapat angka $\mathrm{dl}=1.601 \mathrm{dan} \mathrm{du}=1.731$. Oleh karena itu nilai DW hitung > du (1.898 > 1.731), maka dapat disimpulkan bahwa tidak terdapat autokorelasi dalam model regresi maka model layak untuk digunakan..

\section{Evaluasi dan Pembahasan}

\subsection{Hasil Analisis Regresi Linear Berganda}

Analisis regresi linier berganda digunakan untuk mengetahui besar pengaruh komitmen profesi, sikap kerja dan stres kerja terhadap kinerja pegawai Bidang Kedokteran dan Kesehatan Kepolisian Daerah Sumatera Utara. Analisis dilakukan dengan menggunakan bantuan SPSS dengan output sebagai berikut: 
Tabel 4. Regresi Linear Berganda

Coefficients $^{\mathrm{a}}$

\begin{tabular}{|c|c|c|c|c|c|}
\hline \multirow[t]{2}{*}{ Model } & \multicolumn{2}{|c|}{ Unstandardized Coefficients } & \multirow{2}{*}{$\begin{array}{c}\begin{array}{l}\text { Standardized } \\
\text { Coefficients }\end{array} \\
\text { Beta }\end{array}$} & \multirow[t]{2}{*}{$\mathrm{t}$} & \multirow[t]{2}{*}{ Sig. } \\
\hline & B & Std. Error & & & \\
\hline (Constant) & 17.201 & 1.896 & & 9.073 & .000 \\
\hline Komitmen_Profesi & .461 & .058 & .529 & 7.876 & .000 \\
\hline Sikap_Kerja & .253 & .036 & .466 & 7.006 & .000 \\
\hline Stres_Kerja & -.191 & .057 & -.218 & -3.352 & .001 \\
\hline
\end{tabular}

Sumber: Hasil Pengolahan SPSS Tahun 2020

Berdasarkan pengolahan data yang terlihat pada tabel output kolom kedua bagian B (Unstandardized Coefficients), diperoleh persamaan regresi linier berganda yaitu:

$$
y=a+b_{1} x_{1}+b_{2} x_{2}+b_{3} x_{3}+\varepsilon
$$

$\mathrm{Y}=17.201+0.461 \mathrm{X}_{1}+0.253 \mathrm{X}_{2}+\left(-0.191 \mathrm{X}_{3}\right)+$

$$
\boldsymbol{\varepsilon}
$$

Dengan persamaan regresi linier

berganda tersebut dapat dijelaskan bahwa:

1) Nilai konstanta adalah sebesar 17.201 hal ini menyatakan bahwa jika variable komitmen profesi, sikap kerja dan stres kerja diabaikan, maka nilai kinerja pegawai sebesar 17.201.

2) Koefisien regresi untuk variabel komitmen profesi sebesar 0.529 hal ini menunjukkan bahwa setiap kenaikan $1 \%$ faktor komitmen profesi maka akan meningkatkan kinerja pegawai sebesar $52,9 \%$.
3) Koefisien regresi untuk variabel sikap kerja sebesar 0.466 hal ini menunjukkan bahwa setiap kenaikan $1 \%$ faktor sikap kerja maka akan meningkatkan kinerja pegawai sebesar $46,6 \%$.

4) Koefisien regresi untuk variable stres kerja sebesar -0.218 hal ini menunjukkan bahwa setiap kenaikan $1 \%$ faktor stres kerja maka akan menurunkan kinerja pegawai sebesar $21,8 \%$.

\subsection{Uji Serempak}

Untuk mengetahui pengaruh komitmen profesi, sikap kerja dan stres kerja sebagai variabel bebas $(\mathrm{X})$ terhadap kinerja pegawai sebagai variabel terikat (Y) di Bidang Kedokteran dan Kesehatan Kepolisian Daerah Sumatera Utara dapat dilihat pada tabel 5.17 berikut.

Tabel 5. Hasil Uji Serempak

ANOVA $^{\mathrm{a}}$

\begin{tabular}{|rl|r|r|r|r|r|}
\hline Model & & Sum of Squares & df & Mean Square & F & Sig. \\
\hline \multirow{3}{*}{1} & Regression & 214.251 & 3 & 71.417 & 50.032 & $.000^{\mathrm{b}}$ \\
& Residual & 129.897 & 91 & 1.427 & & \\
& Total & 344.147 & 94 & & & \\
\hline
\end{tabular}

Sumber: Hasil Pengolahan SPSS Tahun 2020

Dari tabel 5. diatas, diperoleh nilai $\mathrm{F}_{\text {hitung }}$ sebesar 50.032. Dengan menggunakan confidence interval (CI) $95 \%$ df 3:95 ( $\alpha=$ 0.05) maka dari tabel distribusi $F$ diperoleh nilai 2.70. Dengan demikian $\mathrm{F}_{\text {hitung }} 50.032>\mathrm{F}_{\text {tabel }}$ 2.70, maka $\mathrm{H}_{0}$ ditolak dan $\mathrm{H}_{1}$ diterima, artinya variabel komitmen profesi, sikap kerja serta stres kerja sebagai variabel bebas (X) berpengaruh signifikan terhadap variabel kinerja pegawai di Bidang Kedokteran dan Kesehatan Kepolisian Daerah Sumatera Utara.

Pada tabel 5.17 di atas terlihat nilai signifikansi sebesar $0.000^{\mathrm{b}}$ lebih kecil dari $\alpha=$
0,05 , hal ini berarti bahwa variabel komitmen profesi, sikap kerja serta stres kerja sebagai variabel bebas memiliki pengaruh yang highly significant. Secara serempak variabel komitmen profesi, sikap kerja serta stres kerja menunjukkan pengaruh sangat nyata terhadap kinerja pegawai di Bidang Kedokteran dan Kesehatan Kepolisian Daerah Sumatera Utara.

\subsection{Uji Parsial}

Uji pengaruh variabel komitmen profesi, sikap kerja serta stres kerja secara parsial dapat dilihat pada tabel 5.19 berikut: 
Tabel 6. Hasil Uji Parsial

Coefficients $^{\mathrm{a}}$

\begin{tabular}{|c|c|c|c|c|c|}
\hline \multirow[t]{2}{*}{ Model } & \multicolumn{2}{|c|}{ Unstandardized Coefficients } & \multirow{2}{*}{$\begin{array}{c}\begin{array}{c}\text { Standardized } \\
\text { Coefficients }\end{array} \\
\text { Beta }\end{array}$} & \multirow[t]{2}{*}{$\mathrm{t}$} & \multirow[t]{2}{*}{ Sig. } \\
\hline & B & Std. Error & & & \\
\hline (Constant) & 17.201 & 1.896 & & 9.073 & .000 \\
\hline Komitmen_Profesi & .461 & .058 & .529 & 7.876 & .000 \\
\hline Sikap_Kerja & .253 & .036 & .466 & 7.006 & .000 \\
\hline Stres_Kerja & -.191 & .057 & -.218 & -3.352 & .001 \\
\hline
\end{tabular}

Sumber: Hasil Pengolahan SPSS Tahun 2020

Dari tabel 6 diatas diperoleh nilai $t_{\text {hitung }}$ masing-masing variabel. Nilai $t_{\text {hitung }}$ tersebut selanjutnya dibandingkan dengan nilai $t_{\text {tabel }}$ pada tingkat kepercayaan $95 \%$ atau $\alpha=0,05$. Nilai $t_{\text {tabel }}$ pada df 3:95 dengan $\alpha=0,05$ adalah 1.985.

Pengaruh parsial dari variabel komitmen profesi $\left(\mathrm{X}_{1}\right)$ diperoleh dengan nilai $\mathrm{t}_{\text {hitung }}$ sebesar 2.988 , dengan demikian $t_{\text {hitung }}>t_{\text {tabel }}(7.876>$ 1.985) dan nilai signifikan sebesar $0.000<0.05$, maka $\mathrm{H}_{0}$ diterima dan $\mathrm{H}_{1}$ ditolak, yang berarti bahwa variabel komitmen profesi $\left(\mathrm{X}_{1}\right)$ berpengaruh positif terhadap kinerja pegawai di Bidang Kedokteran dan Kesehatan Kepolisian Daerah Sumatera Utara. Hal ini berarti bahwa apabila komitmen profesi $\left(\mathrm{X}_{1}\right)$ meningkat, maka kinerja pegawai Bidang Kedokteran dan Kesehatan Kepolisian Daerah Sumatera Utara juga akan meningkat.

Pengaruh parsial dari variabel sikap kerja $\left(\mathrm{X}_{2}\right)$ diperoleh dengan nilai $\mathrm{t}_{\text {hitung }}$ sebesar 7.006, dengan demikian $t_{\text {hitung }}>t_{\text {tabel }}(7.006>1.985)$ dan nilai signifikan sebesar $0.000<0.05$, maka $\mathrm{H}_{0}$ ditolak dan $\mathrm{H}_{1}$ diterima, yang berarti bahwa variabel sikap kerja $\left(\mathrm{X}_{2}\right)$ berpengaruh positif dan signifikan terhadap kinerja pegawai Bidang Kedokteran dan Kesehatan Kepolisian Daerah Sumatera Utara. Hal ini berarti bahwa apabila sikap kerja $\left(\mathrm{X}_{2}\right)$ meningkat maka kinerja pegawai Bidang Kedokteran dan Kesehatan Kepolisian Daerah Sumatera Utara akan meningkat.
Pengaruh parsial dari variabel stres kerja $\left(\mathrm{X}_{3}\right)$ diperoleh dengan nilai $\mathrm{t}_{\text {hitung }}$ sebesar -3.352 , dengan demikian $\mathrm{t}_{\text {hitung }}<\mathrm{t}_{\text {tabel }}(-3.352<1.985)$ dan nilai signifikan sebesar $0.001<0.05$, maka $\mathrm{H}_{0}$ diterima dan $\mathrm{H}_{1}$ ditolak, yang berarti bahwa variabel stres kerja $\left(\mathrm{X}_{3}\right)$ berpengaruh negatif dan signifikan terhadap kinerja pegawai Bidang Kedokteran dan Kesehatan Kepolisian Daerah Sumatera Utara. Hal ini berarti bahwa apabila stres kerja $\left(\mathrm{X}_{3}\right)$ meningkat maka kinerja pegawai Bidang Kedokteran dan Kesehatan Kepolisian Daerah Sumatera Utara juga akan menurun.

Berdasarkan hasil analisis diketahui bahwa nilai koefisien regresi yang paling tinggi adalah variabel komitmen profesi $\left(\mathrm{X}_{1}\right)$ sebesar 0.529 atau $52,9 \%$. Hal ini berarti bahwa komitmen profesi $\left(\mathrm{X}_{1}\right)$ berpengaruh lebih dominan terhadap kinerja pegawai Bidang Kedokteran dan Kesehatan Kepolisian Daerah Sumatera Utara.

\subsection{Uji Determinasi}

Selanjutnya berdasarkan nilai koefisien determinasi $\left(\mathrm{R}^{2}\right)$ diketahui besarnya pengaruh perubahan variabel komitmen profesi, sikap kerja serta stres kerja terhadap kinerja pegawai di Bidang Kedokteran dan Kesehatan Kepolisian Daerah Sumatera Utara sebagai berikut:

Tabel 7. Koefisien Determinasi

Model Summary ${ }^{\mathrm{b}}$

\begin{tabular}{|c|c|c|c|c|c|c|}
\hline \multirow[t]{2}{*}{ Model } & \multirow[t]{2}{*}{$\mathrm{R}$} & \multirow[t]{2}{*}{ R Square } & \multirow{2}{*}{$\begin{array}{l}\text { Adjusted R } \\
\text { Square }\end{array}$} & \multirow{2}{*}{$\begin{array}{l}\text { Std. Error of } \\
\text { the Estimate }\end{array}$} & \multicolumn{2}{|c|}{ Change Statistics } \\
\hline & & & & & $\begin{array}{l}\text { R Square } \\
\text { Change }\end{array}$ & F Change \\
\hline 1 & $.789^{\mathrm{a}}$ & .623 & .610 & 1.195 & .623 & 50.032 \\
\hline
\end{tabular}

Sumber: Hasil Pengolahan SPSS Tahun 2020

Berdasarkan table 7 diatas diperoleh angka Adjusted $R$ Square sebesar 0.610 atau (61\%).
Hal ini menunjukkan bahwa persentase sumbangan pengaruh variabel independen 
(komitmen profesi, sikap kerja serta stres kerja) terhadap variabel dependen (kinerja pegawai) sebesar $61 \%$. Atau variasi variabel independen yang digunakan dalam model (komitmen profesi, sikap kerja serta stres kerja) mampu menjelaskan sebesar 61\%variasi variabel dependen (kinerja pegawai). Sedangkan sisanya sebesar 39\% dipengaruhi atau dijelaskan oleh variabel lain yang tidak dimasukkan dalam model penelitian ini.

\section{Kesimpulan}

Dari hasil analisis yang telah dibahas, maka ditarik kesimpulan sebagai berikut:

1) Komitmen profesi, sikap kerja dan stres kerja menunjukkan pengaruh sangat nyata terhadap kinerja pegawai Bidang Kedokteran dan Kesehatan Kepolisian Daerah Sumatera Utara dengan nilai $F_{\text {hitung }}$ $50.032>\mathrm{F}_{\text {tabel }} 2.70$ dan nilai signifikansi sebesar $0.000^{\mathrm{b}}$.

2) Komitmen profesi berpengaruh positif dan signifikan terhadap kinerja pegawai Bidang Kedokteran dan Kesehatan Kepolisian Daerah Sumatera Utara dengan nilai $t_{\text {hitung }}>$ $\mathrm{t}_{\text {tabel }}(7.876>1.985)$ dan nilai signifikansi sebesar 0.000 .

3) Sikap kerja berpengaruh positif dan signifikan terhadap kinerja pegawai Bidang Kedokteran dan Kesehatan Kepolisian Daerah Sumatera Utara dengan nilai $t_{\text {hitung }}<$ $\mathrm{t}_{\text {tabel }}(7.006>1.985)$ dan nilai signifikansi sebesar 0.000 .

4) Stres kerja berpengaruh negatif dan signifikan terhadap kinerja pegawai Bidang Kedokteran dan Kesehatan Kepolisian Daerah Sumatera Utara dengan nilai $t_{\text {hitung }}<$ $\mathrm{t}_{\text {tabel }}(-3.352<1.985)$ dan nilai signifikan sebesar 0.001 .

5) Angka Adjusted $R$ Square sebesar 0.610 atau (61\%) menunjukkan bahwa persentase sumbangan pengaruh variabel independen (komitmen profesi, sikap kerja dan stres kerja) terhadap variabel dependen (kinerja pegawai) sebesar $61 \%$.

\section{DAFTAR PUSTAKA}

Cascio, Wayne F.,( (2006) Managing Human Resources: Productivity, Quality of Work Life, Profits, edition, New York, McGraw Hill

Colquitt, J. A., LePine, J. A., and Wesson., (2009) Organizational Behavior: Improving Performance and Commitment in the Workplace, New York, McGraw Hill, pp. 37
Cross, T.M dan Lynch. R.R. (2012). Peniliaian dan Evaluasi Kinerja: Konsep dan Praktik. Jakarta. Penerbit Ghalia Indonesia

Dessler, Gary. (2007). Manajemen Sumber Daya Manusia (Jilid I). Jakarta : Indeks.

Gibson, James L., Ivancevich, John M., Donnely, James H., and Konopaske (2009) Organizations: Behavior, Structure, Processes, New York, McGraw Hill.

Hasibuan, Malayu S. P. (2008). Manajemen Sumber Daya Manusia. Edisi Revisi Jakarta: PT. Bumi Aksara.

Ivancevich, G., and Koropaske, D., (2007) Organizations: Behavior, Stucture, Process, Singapore, McGraw Hill Company

Ivancevich, John M., Konopaske, Robert., and Matteson, Michael T., (2007) Organizational Behavior and Management, $7^{\text {th }}$ edition, McGraw Hill, Alih Bahasa Gina Gania, Perilaku dan Manajemen Organisasi, Jilid 1, Edisi 7, Jakarta, Erlangga

Liao (2012), The impact of work values, work attitudes on job performance of Green Energy Industry Employee in Taiwan

Mangkunegara, Anwar, Prabu. (2009). Evaluasi Kinerja SDM, Cetakan 4, Bandung : Refika Aditama

Murphy, S. E., and Pirozzolo, F. J., (2012) Multi Journal ple Intelligences and Leadership, New Jersey, Lawrence Erlbaum

Noviansyah dan Zunaidah (2011). Pengaruh sikap kerja dan motivasi kerja terhadap kinerja pegawai PT. Perkebunan Minanga Ogan Baturaja. Jurnal Manajemen dan Bisnis Sriwijaya Vol.9 No.18

Petty, Ricard E., Brinol, Pablo., dan Tormala, Zakary L., (2012) "Thought Confidence as a Determinant of Persuasion: The Self ValidationHypothesis", Journal of Personality and Social Psychology, pp. 722734

Riduwan. (2007). Skala Pengukuran VariabelVariabel Bandung : Alfabeta

Rivai, Veithzal dan Sagala, Ella Jauvani. (2009). Manajemen Sumber Daya Manusia Untuk Perusahaan : Dari Teori ke Praktek. Jakarta : PT. Rajagrafindo Persada

Robbins, Stephen P., dan Judge, Timothy A., (2008) Perilaku Organisasi, Terjemahan Edisi Dua Belas, Jakarta, Salemba Empat. (2009) Organizational Behavior, $13^{\text {th }}$ edition, New Jersey, Pearson Education, Upper Saddle River. 
Robbins, Stephen P., and Coulter, Mary., (2007) Management, New Jersey, Pearson Prentice Hall, pp. 489

Samsudin, Sadili. (2009). Manajemen Sumber Daya Manusia. Bandung: CV. Pustaka Setia.

Sedarmayanti. (2004). Good Governance (Kepemerintahan Yang Baik), Bandung : Mandar Maju

Sekaran, U., dan Bougie (2010), Research Methods for Busines. A Skill Building Approach. Fifth Edition. A John Wiley and Sons, Ltd, Publication.

Setyaningdyah Endang, Nimran Umar Kertahadi, Thoyib Armanu (2013). The Effects of Human Resource Competence Oragnizational Commitment and Transactioanl Leadership On Work Discipline, Job satisfaction and Employee's Performance. Interdisciplinary Journal of Contemporary Research in Business. Volume 5, No 4

Sink, R dan Tuttle, J.K. (2009). Evaluasi Kinerja. Jakarta: Indeks Kelompok Gramedia.

Slocum, Herriegel., (2009) "Principles of Organizational Behavior Tweith Edition". Canada South western

Stone, Raymond., (2011) Human Resource Management, Fifth Edition, Australia, John Wiley dan Sons

Sugiyono. (2009). Metode Penelitian Kuantitatif dan Kualitatif dan $R$ dan $D$. Bandung : Alfabeta

Taghavi, Safura., Ebrahimzadeh, Fariman., Bhramzadh, Hossein Ali., dan Masoumeh, Hosseini., (2014) "A Study of the Relationship Between Quality of Worklife and Performance Effectiveness of High School Teachers in Shirvan", International Journal of Academic Research in Business and Social Sciences, Vol. 4, No. 1, ISSN : 2222-6990

Thoha, Miftah. (2001). Birokrasi Indonesia Dalam Era Globalisasi, Pusdiklat Pegawai Depdiknas, Sawangan, Bogor.

Yuliandi (2014). Influence of Competency, knowledge and Role Ambiquity on Job performance and Implication for PPAT Performance. Journal of Economics and Sustainable Development. ISSN 2222-1700, ISSN 2222-2855 (Online), Vol 5 No 17

Zin, R. M., (2004) "Perception of Professional Engineers Toward Quality of Work Life and Organizational Commitment a Case Study",
Gadjah Mada InternationalJournal of Business, 6(3), 323-262 